\title{
STRATEGI SISWA SMP DALAM GENERALISASI HUBUNGAN KOVARIASI
}

\author{
Eny Suryowati \\ STKIP PGRI Jombang \\ enysuryowati@gmail.com
}

\begin{abstract}
ABSTRAK
Salah satu aktivitas dalam belajar matematika adalah melakukan generalisasi. Hubungan fungsional terbagi menjadi dua yaitu hubungan kovariasi dan hubungan korespondensi. Generalisasi hubungan kovariasi merupakan suatu proses untuk mendapatkan suatu pernyataan tentang hubungan perubahan dua kuantitas. Proses tersebut terdiri dari relating, searching dan extending. Penelitian ini bertujuan untuk mendeskripsikan strategi yang digunakan dalam generalisasi hubungan kovariasi pada siswa SMP. Penelitian ini dilaksanakan di SMP Negeri 1 Jombang dan SMP Negeri 2 Jombang, pada semester ganjil tahun pelajaran 2018/2019. Penelitian ini merupakan penelitian kualitatif, pengumpulan datanya melalui think aloud dan wawancara. Subjek dalam penelitian ini ada 2 siswa SMP yang dipilih dari 26 siswa yang melakukan generalisasi hubungan kovariasi. Subjek pertama melakukan generalisasi hubungan kovariasi dengan menggambar model dan menghitung banyaknya pot dan persegi pada setiap model menggunakan operasi perkalian. Sedangkan subjek kedua melakukan generalisasi hubungan kovariasi dengan memperhatikan banyaknya pot dan persegi pada model sebelumnya. Berdasarkan hasil pekerjaan subjek dan wawancara dapat disimpulkan bahwa subjek pertama menggunakan strategi counting dan subjek kedua menggunakan strategi recursion.
\end{abstract}

Kata kunci : generalisasi, hubungan kovariasi, hubungan fungsional

\begin{abstract}
One of the activities in learning mathematics is to make generalizations. Functional relationships are divided into two, namely covariation relationship and correspondence relationship. The generalization of a covariation relationship is a process for obtaining a statement about the relationship of changes in two quantities. The process consists of relating, searching, and extending. This study aims to describe the strategies used in generalizing the covariation relationship in junior high school students. This research was carried out in SMP Negeri 1 Jombang and SMP Negeri 2 Jombang, in the odd semester of the academic year 2018/2019. This research is qualitative research with data collection through think aloud and interviews. The subjects in this study were 2 junior high school students selected from 26 students who generalized the covariation relationship. The first subject generalized the covariation relationship by drawing the model and calculating the number of pots and squares in each model using multiplication operations. Otherwise, the second subject generalized the covariation relationship by observing the number of pots and squares in the previous model. Based on the results of the subject's
\end{abstract}


works and interviews, it can be concluded that the first subject uses the counting strategy and the second subject uses the recursion strategy.

Keywords : generalization, covariation relationship, functional relationship

\section{PENDAHULUAN}

Generalisasi merupakan latihan yang paling otentik pada pembelajaran matematika (Strachota, 2016), karena generalisasi sering dideskripsikan sebagai inti dari aljabar (Cooper \& Warren, 2011; Kieran, 2007). Sehingga generalisasi memiliki peran yang kuat dalam matematika tingkat dasar (National Research Council, 2001; NCTM, 2000, 2006). Peran guru juga sangat diperlukan, guru perlu membiasakan diri dengan berbagai cara untuk mengenalkan generalisasi dengan melibatkan siswa pada suatu aksi generalisasi (Strachota, 2016).

Generalisasi dalam matematika merupakan proses induksi dari beberapa kasus khusus (Yilmas dkk, 2009). Mason dkk (2010) menjelaskan bahwa generalisasi merupakan pencarian pola yang lebih luas dan pencarian hubungan serta pembuatan koneksi dalam suatu level berpikir matematis. Menurut Dumitrascu (2017) generalisasi merupakan dualitas antara perpindahan dari sesuatu yang khusus ke sesuatu yang umum dan melihat sesuatu yang khusus melalui sesuatu yang umum. Kaput (1999) menjelaskan bahwa generalisasi dapat dilakukan pada pola, prosedur, struktur, dan hubungan. Carraher dkk (2008) menjelaskan bahwa generalisasi matematis merupakan suatu pernyataan tentang beberapa sifat atau teknik yang berlaku pada himpunan objek matematis yang lebih luas. Jadi generalisasi pada penelitian ini adalah suatu pernyataan tentang suatu hubungan kovariasi yang berlaku secara umum pada kasus yang diberikan. Pada penelitian ini generalisasi merupakan proses (relating, searching dan extending) untuk mencari hubungan kovariasi yang lebih umum dari suatu pola. Generalisasi pada penelitian ini merupakan generalisasi hubungan kovariasi.

Hubungan kovariasi merupakan salah satu jenis dari hubungan fungsional. Ada dua macam hubungan fungsional yaitu hubungan kovariasi dan hubungan korespondensi (Confrey dan Smith, 1995). Hubungan korespondensi mendeskripsikan hubungan antara dua pola melalui suatu aturan (rumus), mendeskripsikan bagaimana menentukan $y$ atau $f(x)$ jika diberikan suatu nilai $x$ (contoh : $y=4 x+1$ ). Hubungan kovariasi mendeskripsikan hubungan antara dua pola yang menunjukkan bagaimana kuantitas dalam suatu pola berubah pada saat kuantitas yang lain juga berubah (Confrey dan Smith, 1995). Hubungan kovariasi dapat ditunjukkan menggunakan tabel, kata-kata, variabel dan membandingkan representasi yang berbeda (Panorkou dkk, 2014).

Panorkou, dkk (2014) menjelaskan hubungan korespondensi dan hubungan kovariasi dapat ditunjukkan melalui tabel, kata-kata, variabel dan representasi grafik. Untuk mestimulasi siswa membedakan kedua hubungan tersebut dapat menggunakan tugas pola bilangan atau pola geometri dari yang paling mudah ke yang lebih sulit. Tugas tersebut dapat diberikan melalui masalah kontekstual. Siswa akan belajar generalisasi dalam tugas tersebut. Tipe tugas tersebut dapat dilihat pada gambar 1 berikut. 


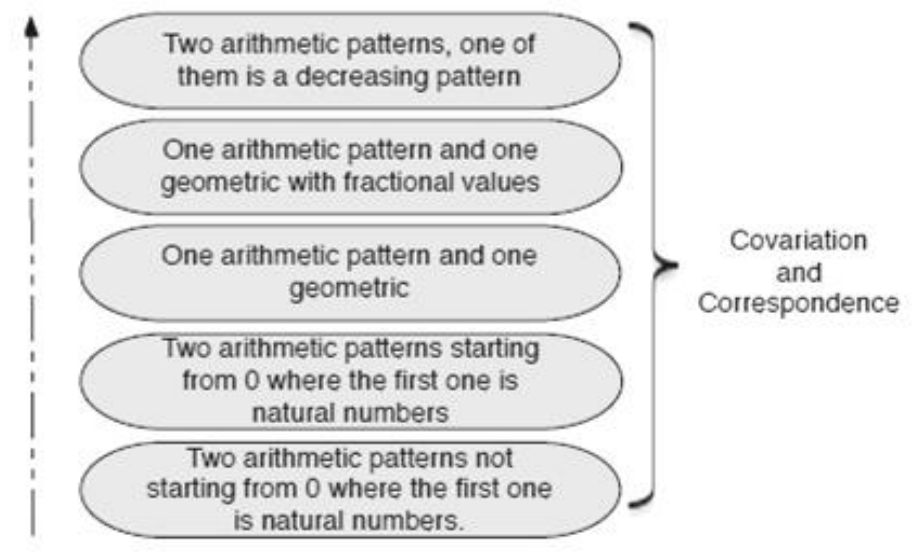

Gambar 1. Tipe tugas

Proses generalisasi pada penelitian ini ditinjau dari aksi generalisasi dan generalisasi refleksi. Aksi generalisasi meliputi relating, searching dan extending (Ellis, 2007). Relating merupakan proses menghubungkan dua objek yang terdapat pada soal. Searching merupakan proses mencari prosedur atau pola yang sama dari gambar yang terdapat pada soal. Extending merupakan proses menerapkan prosedur atau pola yang diperoleh pada searching untuk bilangan yang belum diketahui. Pernyataan siswa saat melakukan aksi generalisasi disebut sebagai generalisasi refleksi (Ellis, 2007). Generalisasi refleksi pada penelitian ini meliputi pernyataan verbal dan tertulis dari subjek. Pernyataan verbal diperoleh saat subjek mengerjakan soal dengan think aloud dan wawancara. Sedangkan pernyataan tertulis diperoleh dari hasil pekerjaan subjek secara tertulis. Jadi antara aksi generalisasi dan generalisasi refleksi tidak dapat dipisahkan, karena setiap melakukan aksi generalisasi pasti akan muncul generalisasi refleksi. Sehingga generalisasi dalam penelitian ini mencakup aksi generalisasi dan generalisasi refleksi.

Untuk melakukan generalisasi diperlukan strategi, beberapa strategi yang dapat digunakan siswa dalam melakukan generalisasi, antara lain counting, recursion, whole object, contextual, guess and check, dan rate-adjust (Lannin, 2003). Strategi counting, dilakukan dengan menggambar atau mengonstruksi suatu model yang mewakili situasi tertentu dan menghitung berdasarkan sifat yang diminta. Strategi recursion, dilakukan dengan menentukan aturan selanjutnya berdasarkan aturan sebelumnya. Strategi whole-object menggunakan bagian dari suatu unit untuk mengonstruk unit yang lebih besar menggunakan perkalian unit. Pada strategi contextual, mengonstruk rumus (aturan) pada hubungan dasar yang ditentukan dari situasi yang terdapat pada soal. Strategi guess dan check, dilakukan dengan menduga suatu aturan tanpa memperhatikan alasannya. Strategi rate-adjust, menggunakan rata-rata perubahan tetap sebagai faktor pengali.

Penelitian ini menambah hasil penelitian dari Carraher, dkk (2008) dan Canadas, dkk (2016). Penelitian Carraher menunjukkan bahwa siswa kelas 3 sekolah dasar sudah dapat melakukan generalisasi melalui beberapa cara dan menghasilkan generalisasi rekursif. Penelitian Canadas menunjukkan bahwa siswa kelas 2 dapat memahami hubungan fungsional dengan istilah doubling (menambah bilangan yang sama kepada diri sendiri). Siswa mengubah masalah dari situasi yang terdapat pada soal ke dalam konteks matematis dan sebaliknya. 
Berdasarkan penjelasan di atas, rumusan masalah pada penelitian ini yaitu bagaimana strategi siswa SMP dalam generalisasi hubungan kovariasi?. Tujuan penelitian ini adalah untuk mendeskripsikan strategi yang digunakan siswa dalam generalisasi hubungan kovariasi.

\section{METODE}

Penelitian ini menggunakan pendekatan kualitatif. Penelitian kualitatif merupakan suatu penelitian yang menyelidiki suatu fenomena sosial atau masalah manusia (Creswell, 2012). Beberapa ciri penelitian kualitatif menurut Creswell (2010) yaitu (1) lingkungan alamiah, peneliti tidak membawa subjek pada situasi yang sudah disiapkan sebelumnya. (2) Peneliti merupakan instrumen utama, peneliti mengumpulkan data sendiri melalui media perekam audio visual. (3) Beragam sumber data, peneliti mengumpulkan data dari berbagai sumber seperti wawancara, hasil tertulis dari subjek dan think aloud. (4) Analisa data induktif, peneliti membuat kategori-kategori secara induktif dengan mengelola data ke dalam informasi yang lebih abstrak. (5) Pandangan menyeluruh, peneliti berusaha membuat gambaran secara menyeluruh dari masalah yang diteliti.

Penelitian ini dilaksanakan di SMP Negeri 1 Jombang dan SMP Negeri 2 Jombang, pada semester ganjil tahun pelajaran 2018/2019. Penelitian ini menghasilkan data deskriptif, berupa tulisan dan lisan dari subjek penelitian yang berhubungan dengan perilaku yang diamati (Moleong, 2007). Pengumpulan data pada penelitian ini menggunakan think aloud dan wawancara. Siswa mengerjakan soal melalui think aloud atau mengerjakan soal dengan menyuarakan dengan keras apa yang dipikirkan. Peneliti memberikan soal kepada 50 siswa sekolah menengah pertama kelas 8, dari 50 siswa tersebut terdapat 26 siswa yang mengerjakan soal dengan benar melalui think aloud. Setelah mengerjakan soal melalui think aloud kemudian dilakukan wawancara. Dari 26 siswa tersebut diambil 2 jawaban siswa untuk dianalisis.

\section{HASIL DAN PEMBAHASAN}

Soal yang diberikan ke siswa kelas VIII, yaitu : "Seorang penjual bunga membuat beberapa model tempat untuk meletakkan pot bunganya (model seperti gambar 2), pot bunga ditandai bulatan kecil berwarna hitam. Tempat tersebut dibuat dengan menyisakan ruang kosong ditengahnya berbentuk persegi. Jika ada satu persegi sebagai ruang kosong maka tempat tersebut dapat digambar seperti model 1 . Jika ada dua persegi sebagai ruang kosong maka tempat tersebut dapat digambar seperti model 2. Jika ada tiga persegi sebagai ruang kosong maka tempat tersebut dapat digambar seperti model 3, begitu seterusnya dibuat secara konsisten sampai memenuhi toko bunga. Bagaimanakah hubungan penambahan persegi terhadap banyaknya pot?"

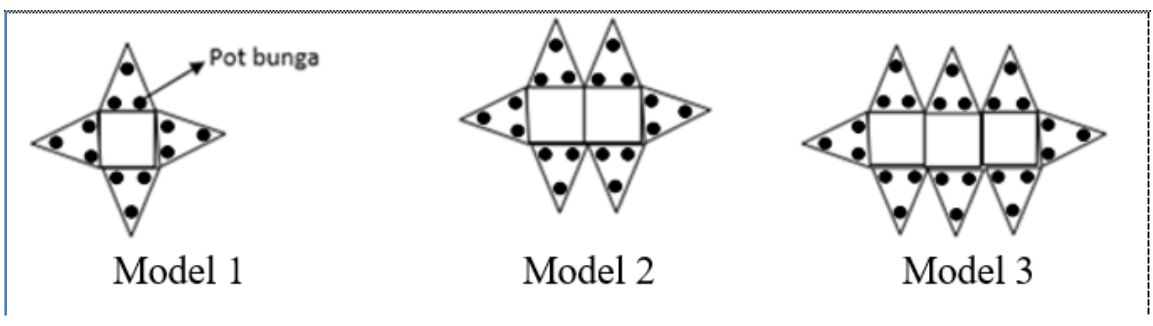

Gambar 2. Model tempat untuk meletakkan pot bunga 
Siswa mengerjakan soal tersebut secara think aloud kemudian dilakukan wawancara. Berikut akan dideskripsikan strategi yang dilakukan subjek saat melakukan generalisasi hubungan kovariasi.

\section{Strategi Subjek 1 (S1) dalam Generalisasi Hubungan Kovariasi}

Berikut hasil think aloud S1 :

S1 : ...jadi di sini jika ada satu ruang kosong kotak ini maka tempat pot bunganya ada 3 kali 4 sama dengan 12, jika ada dua ruang kosong maka ada ...(subjek menghitung banyaknya pot pada model 2 dan model 3),..Jika ada satu ruang kosong maka ada 3 dikali $4 \ldots 12$ pot bunga, jika dua ruang kosong maka ada 3 dikali 6 ...18 pot bunga, jika ada tiga ruang kosong maka ada 3 dikali $8 \ldots 24$ pot bunga. Dari sini kita dapat menyimpulkan bahwa jika ada satu ruang kosong ada 12 pot bunga, dua ruang kosong 18 pot bunga dan tiga ruang kosong 24 pot bunga. Jika menambah satu ruang kosong maka akan menambah dua segitiga atau enam pot bunga. Maka pola atau model ke 4 bisa disimpulkan tiga ruang kosong ada delapan segitiga. Jika menambah satu ruang kosong maka akan menambah dua segitiga atau enam pot bunga. Maka pola atau model ke 4 bisa disimpulkan tiga ruang kosong ada delapan segitiga. Jadi hubungan penambahan persegi terhadap banyaknya pot adalah jika menambah satu ruang kosong maka pot akan bertambah sebanyak 6 buah.

Berdasarkan hasil think aloud, Subjek 1 menggambar model seperti yang terdapat pada soal dan menghitung banyaknya persegi dan segitiga pada model yang diketahui dengan mengalikan 3 dengan banyaknya persegi. Dikalikan 3 karena banyaknya pot dalam satu segitiga ada 3. Subjek menemukan bahwa setiap model bertambah dua segitiga atau enam pot bunga. Subjek menentukan banyaknya pot pada model keempat. Kemudian subjek menyimpulkan jika menambah satu ruang kosong (persegi) maka pot akan bertambah enam buah.

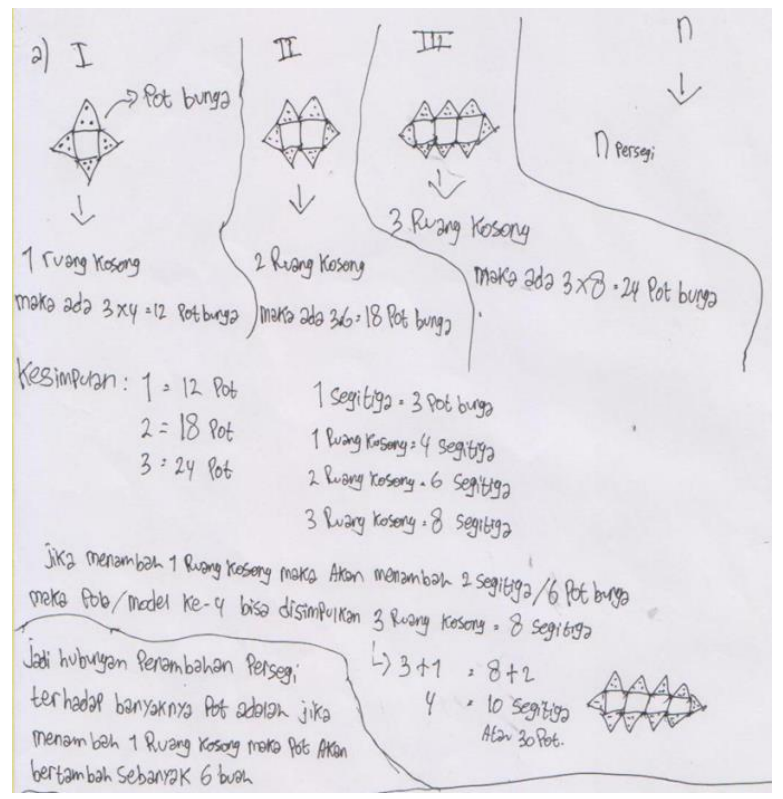

Gambar 3. Hasil pekerjaan Subjek 1 
Berikut beberapa penggalan wawancara dengan Subjek 1.

$\mathrm{P}$ : setelah menggambar model tempat untuk meletakkan pot bunga, apa yang saudara lakukan?

S1 : pertama, ...jika ada satu ruang kosong atau persegi maka ada 12 pot dan satu ruang kosong ada empat segitiga dan satu segitiga berisi tiga pot bunga, maka jika ada satu ruang kosong pertama ada tiga kali empat segitiga maka ada dua belas, dan jika satu pertambahan ruang kosong maka akan bertambah dua segitiga atau dengan kata lain bertambah enam

$\mathrm{P}$ : ruang kosong itu apa?

$\mathrm{S} 1$ : ruang kosong itu persegi.

$\mathrm{P}$ : dari mana saudara tahu kalau bertambah sebanyak enam?

S1 : jika ada satu ruang kosong ada dua belas pot digambar selanjutnya ada dua ruang kosong (sambil menunjuk gambar yang sudah dibuat) dari sini kita bisa lihat ada pertambahan satu ruang kosong atau penambahan persegi, disini segitiganya ada ...di pola pertama ada satu dua tiga empat dan di pola ke dua ada satu dua tiga empat lima enam begitu juga seterusnya pada pola tiga ada tiga ruang kosong, dari enam buah segitiga di pola yang ke tiga ini bertambah dua buah segitiga atau enam buah pot.

$\mathrm{P}$ : jadi hubungan penambahan persegi terhadap banyaknya pot bagaimana?

$\mathrm{S} 1$ : jika ruang kosong atau persegi ditambah satu maka otomatis pot bunga atau segitiga juga bertambah sebanyak dua segitiga dengan kata lain enam buah pot.

Berdasarkan hasil think aloud, wawancara, serta hasil pekerjaan Subjek 1, pada aksi relating subjek menghubungkan banyaknya pot dan segitiga. Hal ini terlihat dari pekerjaan subjek (gambar 3) yang menghitung banyaknya pot saat menghitung banyaknya pot pada setiap model. Subjek juga menghubungkan banyaknya ruang kosong dengan banyaknya pot pada setiap model yang diketahui. Ruang kosong pada model adalah suatu persegi yang terdapat pada model.

Aksi searching, subjek menentukan prosedur untuk menghitung banyaknya pot dengan mengalikan banyaknya pot pada satu segitiga dengan banyaknya segitiga pada setiap model yang diketahui. Berdasarkan prosedur yang diperoleh untuk menghitung banyaknya pot pada model yang diketahui, subjek menyimpulkan ada kesamaan prosedur untuk menghitung banyaknya pot pada setiap model.

Pada aksi extending, subjek menentukan banyaknya pot pada model selanjutnya (model 4). Subjek menggunakan keteraturan prosedur yang ditemukan saat searching untuk menentukan hubungan penambahan persegi terhadap banyaknya pot. Generalisasi refleksi subjek terlihat pada jawaban tertulis dan lisan saat wawancara.

Berdasarkan hal tersebut, dapat diketahui bahwa subjek menggunakan strategi counting. Subjek menggambar model pot kemudian menghitung banyaknya pot menggunakan prosedur perkalian bilangan. Subjek mengetahui adanya keteraturan prosedur pada model tersebut.

\section{Strategi Subjek 2 (S2) dalam Generalisasi Hubungan Kovariasi}

\section{Berikut hasil think aloud S2:}

S2 : disini pada model 1 , terdapat 1 persegi yang diikuti dengan 12 pot. pada model $2 \ldots 2$ buah persegi dan 18 pot dan model $3 \ldots 3$ persegi dan 24 pot, dari model 1 ke model 2 memiliki beda 6 pot dan 1 persegi. Dari model 2 ke model 3 juga seperti itu ...6 pot dan 1 persegi. Sehingga hubungan penambahan persegi terhadap banyaknya pot adalah setiap bertambah 1 persegi, maka pot juga akan bertambah sebanyak 6 pot. 
Berdasarkan hasil think aloud diketahui Subjek 2 menghitung dengan membilang banyak persegi dan pot dari setiap model yang diketahui. Kemudian Subjek 2 menentukan selisih banyaknya pot dari model 1, 2 dan 3. Setelah itu Subjek 2 menyimpulkan jika persegi bertambah 1 maka bertambah 6 pot, seperti yang terdapat pada jawaban Subjek 2 pada gambar 4 berikut ini.

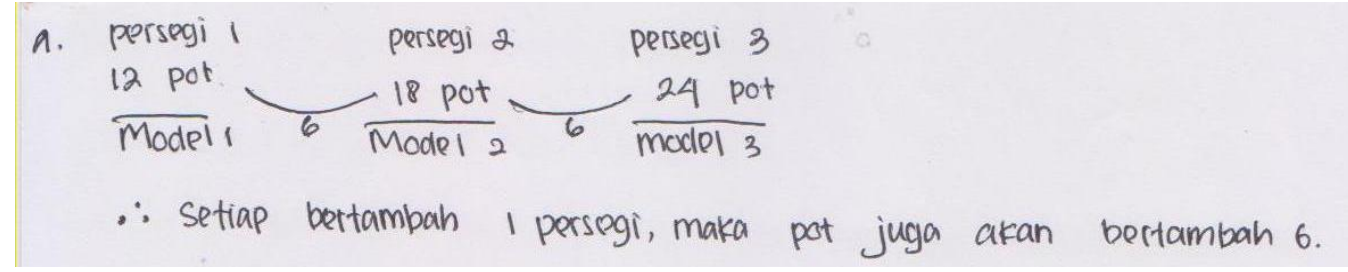

Gambar 4. Hasil pekerjaan Subjek 2

Berikut beberapa penggalan wawancara dengan Subjek 2 :

$\mathrm{P}$ : Saudara tadi menuliskan ini ya ...persegi 112 pot model 1. Ini Saudara peroleh dari mana informasi ini?

S2 : ini dari diamatin gambar ini sama mengamati pola bilangannya. Jadi dicari dulu berapa jumlahnya setiap penambahan.

$P$ : jumlah apa?

S2 : jadi ini kan ada kotak dikelilingi oleh pot-pot, setiap nambah kotak ini potnya juga nambah, jadi nanti dari selisihnya kita bisa tahu nambah berapa setiap bertambah kotaknya.

$\mathrm{P}$ : di situ (sambil menunjuk ke jawaban subjek) ada tulisan enam, apa maksudnya?

S2 : enam, ini model 1 gambarnya perseginya ada 1 potnya ada 12 , kalau perseginya ada dua 18 pot, persegi 324 pot...jadi ini selisih potnya dari model 1 ke model 2 itu ada 6 , dan ini juga ada 6 (sambil menunjuk ke jawaban) berarti itu setiap nambah persegi nambah 6 pot.

$\mathrm{P}$ : nambah berapa perseginya?

S2 : setiap bertambah 1 persegi menambah menjadi potnya nambah 6 .

$\mathrm{P}$ : jadi bagaimanakah hubungan penambahan persegi terhadap banyaknya pot ?

S2 : jadi setiap bertambahnya 1 persegi pada taman itu maka pot juga akan bertambah menjadi 6 .

Berdasarkan hasil think aloud, wawancara dan hasil pekerjaan Subjek 2, pada aksi relating subjek menghubungkan banyaknya persegi dan pot. Subjek menentukan banyaknya pot dengan menghitung tanpa menggunakan perkalian. Subjek menghitung banyaknya pot dengan membilang (menghitung langsung pot yang ada pada gambar). Subjek mengelompokkan setiap unsur pada model sesuai dengan model yang ada.

Aksi searching, subjek menentukan selisih banyaknya pot dan persegi dari model 1 dengan model 2 dan banyaknya pot dari model 2 dengan model 3. Subjek mengetahui jika ada kesamaan selisih sebanyak 6 pot dari model yang diketahui.

Pada aksi extending, subjek menggunakan selisih banyak pot dari setiap model yang diketahui untuk menentukan hubungan penambahan persegi terhadap banyaknya pot. Subjek menentukan hubungan itu dari aturan (pola) sebelumnya (dari model 1, model 2 dan model 3). Generalisasi refleksi subjek terlihat pada jawaban tertulis dan lisan saat wawancara. 
Berdasarkan hal tersebut, dapat diketahui bahwa subjek menggunakan strategi recursion. Subjek membuat kesimpulan hubungan kovariasi dari dua kuantitas melalui pola (aturan) pada model sebelumnya.

\section{SIMPULAN}

Strategi yang digunakan subjek dalam generalisasi hubungan kovariasi pada penelitian ini adalah counting dan recursion. Pada strategi counting, subjek menggambar model yang terdapat pada soal, kemudian subjek menghitung banyaknya unsur pada model untuk membuat pernyataan hubungan perubahan dua kuantitas yang terdapat pada model. Sedangkan pada strategi recursion, subjek mendapat suatu pola (aturan) pada model sebelumnya untuk digunakan membuat pernyataan hubungan perubahan dua kuantitas yang terdapat pada model.

\section{DAFTAR PUSTAKA}

Canadas, M.C., Brizuela, B.M., and Blanton, M. 2016. Second Graders Articulating Ideas About Linear Functional Relationships. The Journal of Mathematical Behavior, Vol. 41 : 87-103.

Carraher, D.W., Martinez, M.V., and Schliemann, A.D. 2008. Early Algebra and Mathematical Generalization. ZDM Mathematics Education, Vol. 40 : 3-22.

Confrey, J., and Smith, E. 1995. Splitting, Covariation, and Their Role in The Development of Exponential Function. Journal for Research in Mathematics Education, Vol. 26 : 66-86.

Cooper, T., and Warren, E. 2011. Year 2 to Year 6 Students' Ability to Generalize: Models, Representations and Theory for Teaching and Learning. In Early Algebraization: A Global Dialogue from Multiple Perspectives. Heidelberg: Springer.

Creswell, J. 2010. Research Design: Qualitative, Quantitative and Mixed Methods Approaches. California: Saga Publication.

Creswell, J.W. 2012. Educational Research : Planning, Conducting and Evaluating Quantitative and Qualitative Research. Pearson Education Inc.

Dumitrascu, G. 2017. Understanding The Process of Generalization in Mathematics Through Activity Theory. International Journal of Learning, Teaching and Educational Research, Vol.16(12) : 46-69.

Ellis, A. B. 2007. Taxonomy for Categorizing Generalizations : Generalizing Action and Reflection Generalization. The Journal of The Learning Science, Vol. 16 : 221-261.

Kaput, J. 1999. Teaching and Learning a New Algebra with Understanding. In Mathematics Classroom that Promote Understanding. Mahwah, NJ: Erlbaum.

Kieran, C. 2007. Learning and Teaching Algebra at The Middle School Through College Levels: Buliding Meaning for Symbols and Their Manipulation. In Second Handbook of Research on Mathematics Teaching and Learning. Greenwich: Information Age Publishing.

Lannin, John K. 2003. Developing Algebraic Reasoning Through Generalization. Mathematics Teaching in The Middle School. NCTM.

Mason, J., Stacey, K., and Burton, L. 2010. Thinking Mathematically. Edinburgh: Pearson.

Moleong, L. J. 2007. Metodologi Penelitian Kualitatif. Bandung: Remaja Rosdakarya. 
National Research Council. 2001. Adding it Up: Helping Children Learn Mathematics. Washington, DC: National Academy of Sciences.

NCTM. 2000. Principles and Standars for School Mathematics. Reston, VA: NCTM.

NCTM. 2006. Curriculum Focal Points K-8. Reston, VA: NCTM.

Panorkou, N., Maloney, A.P., and Confrey, J. 2014. Expressing Covariation and Correspondence Relationships in Elementary Schooling. NCTM.

Strachota, S. 2016. Conceptualizing Generalization. IMVI Open Mathematical Education Notes, Vol. $6: 41-45$.

Yilmaz, R., Argun, Z., and Keskin, M.O. 2009. What is the Role Visualization in Generalization Processes: The Case of Pre-Service Secondary Mathematics Teachers. Humanity and Social Sciences Journal, Vol. 4(2) : 130-137. 